\title{
Grazing Capacity and Stocking Rate
}

\author{
DEE GALT, FRANCISCO MOLINAR, JOE NAVARRO, JAMUS JOSEPH, AND JERRY HOLECHEK
}

$\mathrm{D}$ uring the past 5 years grazing capacity surveys have been increasingly used in range management decisions on both public and private lands in the western United States. They are also becoming more used in developing countries such as South Africa, Australia, Brazil, and Mexico. Range professionals and ranchers are better recognizing that successful range management depends on stocking rangelands so adequate vegetation residues remain to protect rangeland health, maintain multiple values, and insure economic viability. Recently there has been growing support for changes in existing government programs as well as new programs that would encourage conservative grazing on both public and private rangelands. Sound stocking rate and grazing capacity procedures will be essential if these programs are to be successfully implemented.

\section{What is Grazing Capacity?}

Government subsidies for brush control and seeding on both public and private lands are now under intensive attack from environmental groups.. the number of animal units that will be assigned to the allotment. This is the basis for value of the permit and grazing fees the rancher will pay. The best approach to determining safe stocking rate on rangelands is knowing the numbers of animals actually grazing a ranch or allotment over a period of years together with utilization levels, range trend analyses, and precipitation records. Incomplete and/or uncertain information on livestock numbers actually grazed, grazing use, and trend has created the demand for formal grazing capacity surveys to better establish the appropriate permit number. Increasingly, environmental groups are participating in the permit renewal process. They are prepared to challenge any decision not based on sound information and, in some cases, those that do have a sound basis. These forces have increased the need for formal grazing capacity determinations based on the best available science.

There is considerable turnover of both public and

Generally, grazing capacity is considered to be the average number of animals that a particular range or ranch will sustain over time. It is based on stocking rate. Stocking rate is defined by the Society for Range Management as the amount of land allocated to each animal unit for the grazable period of the year. Determination of stocking rate and grazing capacity involve the same procedures, except that grazing capacity estimates require adjustment of forage production to the hypothetical average year. We define this hypothetical average year as the average forage production for the previous 10 year period. Ideally, at least 3 years of forage production data should be collected to establish grazing capacity. However, in reality this is often not possible due to management requirements for immediate information and/or funding limitations. Regression equations relating forage production to monthly and annual precipitation have been developed for specific range types. We have found them to be reasonably reliable if no major aberrations occur in precipitation during the survey year. We do caution that grazing capacity is part myth and part reality: The average number of livestock a ranch has carried over the previous 5,10 , or 20 years may have little relevance to what it will support in any given year or group of years.

\section{Applications of Grazing Capacity}

Under present policy, livestock grazing permits on federal lands in the USA are reviewed for renewal every 10 years. They also undergo review when the permit is transferred to another owner. The most basic decision on the new permit is private land ranches in New Mexico and most other western states. Financial success in ranching depends on buying grazing capacity at or below fair market value and properly stocking the ranch after purchase. Ranch buyers are increasingly recognizing that realtor statements, ranch financial records, and public land grazing permits do not necessarily accurately reflect grazing capacity. Another problem is that location and extent of forage resources within ranches or allotments are often poorly identified and quantified. A good grazing capacity survey not only helps to establish ranch value, but it also provides valuable information on infrastructure (water, fence, roads, corrals); ecological condition of various pastures; land unsuited for grazing due to terrain, distance from water, and other constraints; past range use; range trend; noxious plant problems; and wildlife grazing use. Information on key forage species and key areas for monitoring precipitation, trend, grazing use, and forage production should be routinely provided in a grazing capacity survey. Generally, we believe once a grazing capacity survey is conducted, it should be updated every 10 years.

\section{Grazing Capacity Procedures}

Specific procedures for setting stocking rates and establishing grazing capacity are generally well developed. Issues such as key area selection, quantification of forage production, selection of harvest coefficients, corrections for slope and distance to water, and animal forage intake allowances are thoroughly discussed by these papers. However, we believe selection of the harvest coefficient and corrections for slope and distance from water merit further discussion. 


\section{Harvest Coefficient Selection}

The harvest coefficient is the percentage of total forage produced that is assigned to grazing animals for consumption. Holechek (1988) bases harvest coefficient selection on various stocking rate studies from different range types. For most arid and semi-arid areas, a harvest coefficient of $35 \%$ would be selected while $50 \%$ would usually be used for annual grasslands and humid areas.

An alternative, more simple approach involves assigning $25 \%$ of the forage to livestock, $25 \%$ to wildlife and natural disappearance, and $50 \%$ for site protection. This procedure is obviously more restrictive.

We have had the opportunity to make detailed evaluations of actual forage use when the Holechek stocking procedure was applied on several New Mexico rangelands. Consistently, actual measured use has been 10-15\% higher than the intended use. We attribute this to livestock trampling, wildlife consumption, and weathering. On Chihuahuan Desert rangelands, Paulsen and Ares recommended that stocking levels be set for $35 \%$ use of perennial grasses. However, they noted that the harvest coefficient must be set at $30 \%$ to obtain $35 \%$ use because of trampling, wildlife, and weathering losses. Past and recent research has confirmed this wisdom.

Over an 8 year period, pastures on the Chihuahuan Desert Rangeland Research Center in south-central New Mexico assigned a $30 \%$ harvest coefficient, carried nearly as many cattle as those assigned a $40 \%$ harvest coefficient. This was because conservatively stocked pastures produced more forage in drought years and required less destocking. There has also been a substantial improvement in ecological range condition and forage production on the conservatively stocked pastures over time. Cattle productivity was substantially higher in the conservatively stocked pastures.

We increasingly hold the opinion that a $25 \%$ harvest coefficient is a sound idea for most western rangelands. After careful analysis of their own and existing research, Johnston et al. recommended a $25 \%$ harvest coefficient for Australian rangelands. It allows both forage species and livestock to maximize their productivity, allows for error in forage production estimates, greatly reduces problems from buying and selling livestock, reduces the risk of financial ruin during drought years, and promotes multiple use values.

In the Chihuahuan Desert of New Mexico, the rancher who routinely stocks at capacity based on a $25 \%$ harvest coefficient will need to liquidate or dry lot feed about one half their herd in 2 years out of 10 (Table 1). In contrast, the rancher using a $35 \%$ harvest coefficient will need to completely destock in 2 years out of 10 and partially destock in another 1-2 years. We acknowledge that ranchers in the more humid Great Plains rangelands may do better with a $35 \%$ than $25 \%$ harvest coefficient because of less annual variation in forage production.

The authors research and experience across a variety of landscapes, ranches, and countries shows a $25 \%$ harvest coefficient is the surest way to avoid chronic forage deficits and land degradation. Any financial advantages of higher harvest coefficients become doubtful in arid and semi-arid areas if a 10 year or more time horizon is used.

The real problem is that few ranchers have the skills or time/labor resources to annually quantify forage production. Unless this is done, use of higher harvest coefficients than $25 \%$ invariably leads to land degradation and severe financial
Table 1. Ten year variation in forage production on moderately grazed New Mexico Chihuahuan Desert and Colorado mid-grass prairie rangelands.

\begin{tabular}{|c|c|c|c|c|c|}
\hline \multicolumn{3}{|c|}{$\begin{array}{c}\text { Chihuahuan Desert } \\
\text { New Mexico }^{1}\end{array}$} & \multicolumn{3}{|c|}{$\begin{array}{l}\text { Mid-Grass Prairie } \\
\text { Colorado }^{2}\end{array}$} \\
\hline Year & $\begin{array}{c}\text { Annual } \\
\text { precipitation }\end{array}$ & $\begin{array}{c}\text { Forage } \\
\text { production }\end{array}$ & Year & $\begin{array}{c}\text { Annual } \\
\text { precipitation }\end{array}$ & $\begin{array}{l}\text { Forage } \\
\text { production }\end{array}$ \\
\hline & (inches) & (lbs/acre) & & (inches) & (lbs/acre) \\
\hline 1989 & 7.6 & 189 & 1957 & 13.2 & 1141 \\
\hline 1990 & 10.7 & 270 & 1958 & 17.3 & 1489 \\
\hline 1991 & 15.1 & 488 & 1959 & 13.5 & 1095 \\
\hline 1992 & 15.4 & 750 & 1960 & 12.5 & 1140 \\
\hline 1993 & 9.9 & 203 & 1961 & 17.9 & 1508 \\
\hline 1994 & 7.0 & 6 & 1962 & 16.4 & 1314 \\
\hline 1995 & 6.7 & 59 & 1963 & 18.7 & 1327 \\
\hline 1996 & 7.9 & 145 & 1967 & 9.9 & 1179 \\
\hline 1997 & 11.6 & 284 & 1965 & 19.4 & 1197 \\
\hline 1998 & 8.2 & 173 & 1966 & 13.8 & 1267 \\
\hline Average & 10.0 & 257 & & 15.3 & 1266 \\
\hline $\begin{array}{l}\text { Standard } \\
\text { deviation }\end{array}$ & 3.0 & 207 & & 2.9 & 137 \\
\hline $\begin{array}{l}\text { Coefficient } \\
\text { variation }\end{array}$ & 30.2 & 81 & & 18.9 & 11 \\
\hline
\end{tabular}

Source: Holechek et al. 1999

${ }^{2}$ Source: Sims et al. 1976

losses when drought occurs because of rancher reluctance to destock. These losses can quickly eliminate any accumulated benefits of more efficient forage use. Unused forage in wet years provides a reserve of forage for drought and increases plant vigor and soil water infiltration. Rather than a waste, we see it as an investment in the future. New Mexico research shows conservative stocked rangelands produced nearly $50 \%$ more forage than moderate stocked rangelands in drought years. Studies from other range types validate these findings. Early studies showed unused residue can increase forage production by $50 \%$ or more compared to areas where it is removed by grazing.

Some of the most successful ranchers we have encountered have their operations in the Chihuahuan Desert of northern Mexico. Although we found none of them ever took any classes in grazing management, this family has well over 100 years of ranching experience. They are firm believers in light to conservative use of their forage and well distributed watering points. This allows them to maintain their herds with little destocking in the worst of drought years. They shuffle their cattle around to where forage growth is best by manipulating access to water resources. We were amazed at how good their rangeland and cattle looked in the dry years of the mid 1990's (Figure 1).

Heitschmidt and Walker suggested that plant species composition does not impact society's acceptance of a given grazing practice nearly as much as amount of standing biomass, ground cover, number of fecal patties, and so on. They believed grazing technology in the 21 st century will depend heavily on managing residue levels to insure a variety of multiple use values. We believe the $25 \%$ harvest coefficient accomplishes this goal quite well.

\section{Slope Adjustments}

Although the need to adjust grazing capacity for distance from water and slope has long been recognized, Holechek (1988) provides the first formal procedures' for these adjust- 


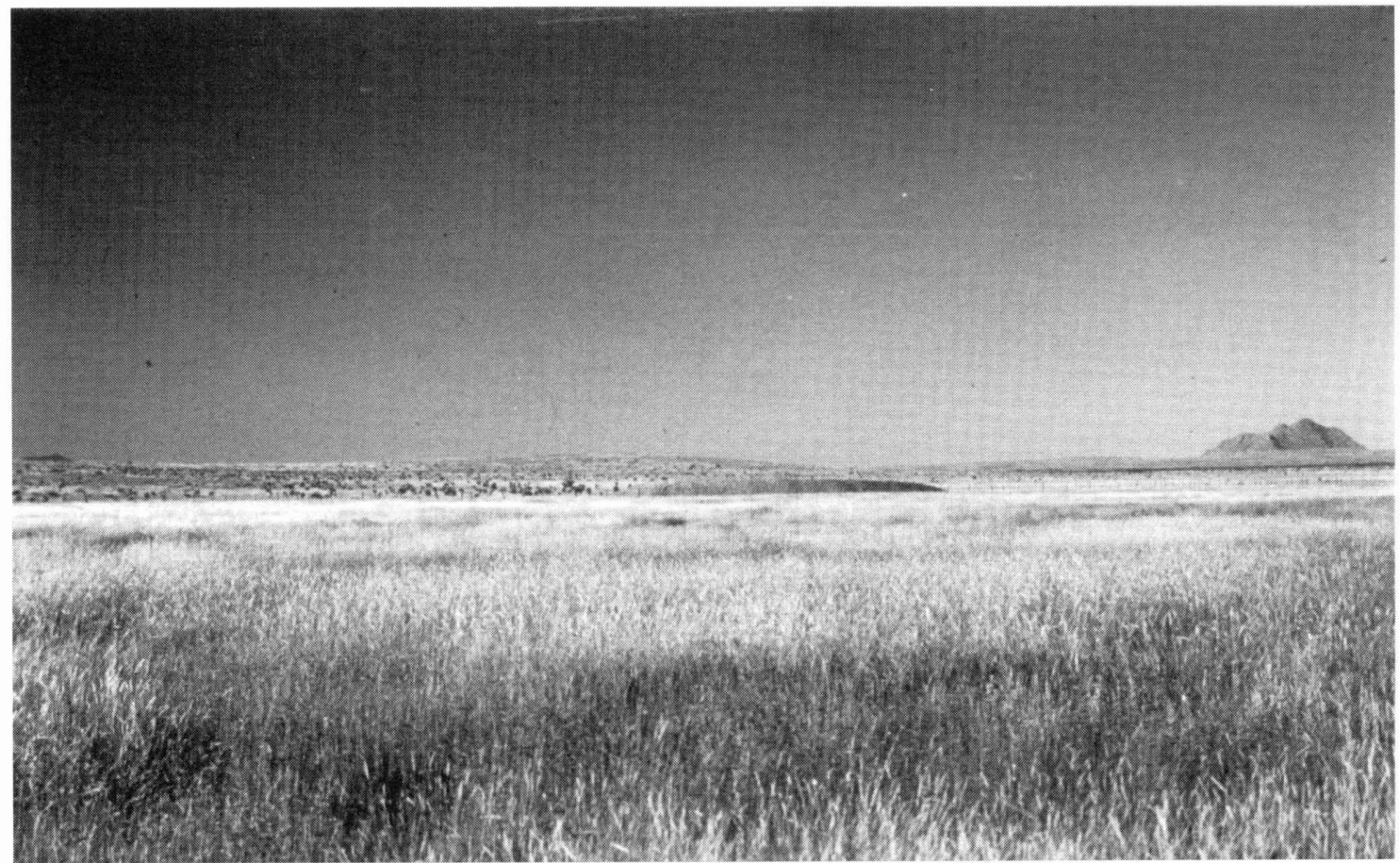

Fig. 1. This Chihuahuan Desert ranch in northern Mexico has a long history of light to conservative stocking. Vegetation is in near climax and the ranch owners have had to do little destocking in dry years. Primary forage grasses in picture are black grama and tobosa.

ments we have found in the literature. His reductions are well supported by previous and present research. Most recently, the United States Department of Agriculture-Natural Resources Conservation Service has adopted Holechek's guidelines. His guidelines involve no reduction for $0-10 \%$ slopes, $30 \%$ reduction for $11-30 \%$ slopes, $60 \%$ reduction for $31-60 \%$ slopes, and $100 \%$ reduction for slopes over $60 \%$. In our grazing capacity surveys in New Mexico we have found Holechek's guidelines to work quite well when actual use was checked against intended use. However, we do believe ranchers who obtain more uniform use of rugged terrain than would be expected should be given some flexibility on slope reductions if they document pasture use patterns.

\section{Educational Benefits}

In our opinion, one of the greatest benefits of a grazing capacity survey is that it creates an opportunity to educate ranchers on range management. During their participation in designing and implementing the survey, most new and many experienced ranchers greatly improve their capability to make sound stocking rate decisions.

From this point, the next steps are establishing a program for rangeland monitoring and a plan to deal with drought. Utilization levels can be practically monitored by the rancher. Through use of the key sites that are representative of the pasture and 0.75 to 1.00 mile from water, qualitative grazing intensity assessments can be made. Percent use of forage can be determined by general appearance of the range at the end of the grazing period. Intensity can also be substantiated by stubble height measurements of key forage species and weight estimates of forage residues remaining on the land. Rain gauges distributed over the pasture can be helpful in assessing forage production and managing drought situations. A sound monitoring program provides many benefits to livestock producers over the long term. It is our experience when ranchers fully consider the problems associated with liquidating and reacquiring livestock during and after drought, their attitudes on stocking rate and grazing capacity change. They better accept the realities of arid land ranching and are more prone to select "safe" or conservative stocking rates.

\section{Political Backdrop}

It is our observation that the whole focus of range management on public and private lands from the 1950's through the 1980 's has centered around keeping stocking rates as high as possible through ranch capitalization (water development, fence, brush control, seeding), often subsidized by the federal government. By the 1990's many ranchers were fully capitalized with water and fence.

Government subsidies for brush control and seeding on both public and private lands are now under intensive attack from environmental groups and are being questioned by members of the range management and ranching communities. Increased enforcement of the Endangered Species Act and the National Environmental Policy Act have made application of various range improvements on public lands more difficult. During the past 20 years brush encroachment has severely reduced forage production on many western rangelands where pinyon-juniper, sagebrush, and other shrubs had been controlled in the 1950's, 1960's, and 1970's (Figure 2).

During the early 1980's the Savory Grazing Method provid- 


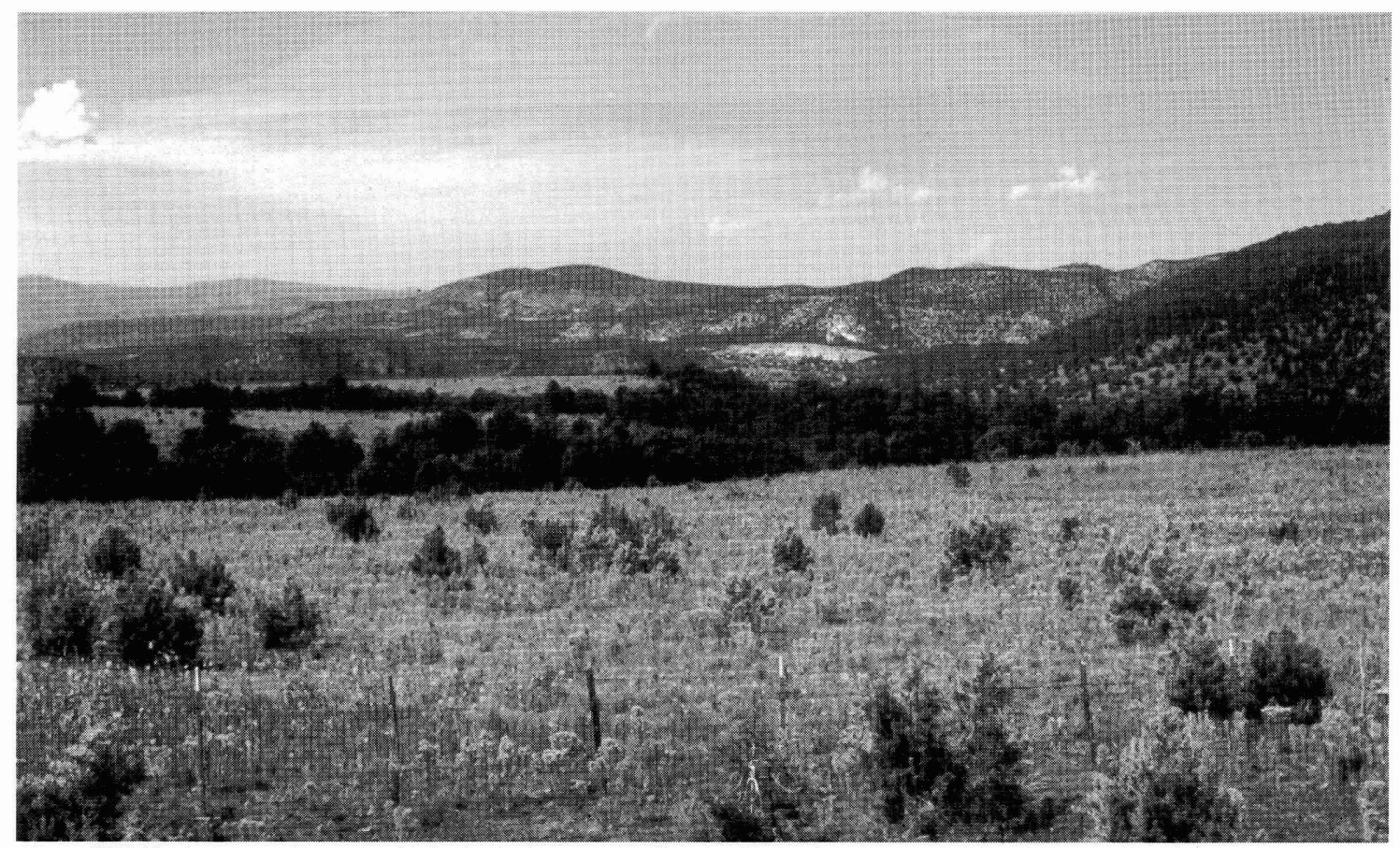

Fig. 2. Encroachment of pinyon-juniper into grasslands is reducing grazing capacity on many New Mexico rangelands. Tree control has become more difficult due to government regulations, reductions in subsidies, and higher costs for improvement. This has necessitated better balancing of animal numbers to existing forage supplies.

ed hope that ranchers could increase their grazing capacity and stocking rates concurrently without use of brush control or seeding. Research has shown that it may not have any stocking rate or forage production advantages over other grazing systems that have been developed (Holechek et al. 1999).

Recently, more environmental leaders, range professionals, and ranchers have advocated conservative stocking as a winwin approach to concurrently increasing grazing capacity and multiple use values. Research showing that conservative stocking can be an effective, low cost way to increase grazing capacity is hardly new. Early studies convincingly showed its biological and financial benefits. The problem has long been that the idea of stocking reductions as a means to increased grazing capacity, has never played well with the ranching community. This is particularly true with large public land ranchers whose net worth and security of grazing privileges are closely associated with livestock numbers specified on their grazing permit. Various reforms have been proposed to remedy this problem, but so far none have been put into legislation.

In spite of resistance from some ranchers and range professionals, balancing animal numbers with existing forage supplies rather than expanding forage supplies through range improvements was increasingly used on public rangelands in New Mexico in the 1990's. Low cattle prices, rising ranching costs, and reductions in range improvement cost sharing subsidies have caused many private land ranchers to consider and apply this same approach. Hence, the new emphasis on establishing grazing capacity and using it as a basis for range management decisions as we move into the $21^{\text {st }}$ century.

\section{Analysis and Implications}

We believe that in the $21^{\text {st }}$ century, various range management decisions on public and private rangelands will depend heavily on grazing capacity surveys. Over the past 10 years several similar scientifically based procedures for determining stocking rates and grazing capacity have been developed. They are becoming somewhat standardized on animal intake rates, forage production determination, key area selection, and adjustments for slope and distance from water. Many range professionals now advocate a $25 \%$ harvest coefficient when grazing capacity and stocking rates are assigned. We believe this idea has considerable merit for arid and semi-arid areas from vegetation, livestock production, and multiple use standpoints.

Grazing capacity surveys provide a basis for ranch value, annual adjustments in stocking rates, grazing fees on public lands, and may soon be used in administration of subsidies that promote conservative stocking. They can also play an important role in allocation of forage to livestock and wildlife. While a sound grazing capacity survey can help establish the number of livestock a ranch will support through time, it must always be recognized that grazing capacity may have little relevance to livestock numbers sustainable in a given year or group of years. Although a good grazing capacity survey can be helpful in many range management decisions, it should not become a replacement for information on range trend, grazing use, and range condition. 


\section{References and Other Reading}

Anderson, C. 1994. Overgrazing destroys income-producing rangeland. Texas Section, Society for Range Management, Grass Roots p. 7.

Beutner, E. L. and D. Anderson. 1943. The effect of surface mulches on water conservation and forage production in some semi-desert grassland soils. J. Amer. Soc. Agron. 33:393-400.

Heitschmidt, R. K. and J. W. Walker. 1996. Grazing management: Technology for sustaining rangeland ecosystems. Austr. Rangel. J. 18:194-215.

Holechek, J. L. 1988. An approach for setting the stocking rate. Rangelands 10:10-14.

Holechek, J. L. and D. Galt. 2000. Grazing intensity guidelines. Rangelands 21:(3)11-14.

Holechek, J. L. and K. Hess. 1994. Free market policy for public land grazing. Rangelands 16:63-67.

Holechek, J. L. and K. Hess, Jr. 1996. Market forces would benefit rangelands. Forum for Appl. Res. and Public Policy 2:5-15.

Holechek, J. L., M. Thomas, F. Molinar, and D. Galt. 1999. Stocking desert rangelands: What we've learned. Rangelands 21(6):8-12.

Holechek, J. L., H. Gomes, F. Molinar, D. Galt, and R. Valdez. 2000. Short-duration grazing: The facts in 2000 . Rangelands 21(5):18-22.

Hutchings, S. S. and G. Stewart. 1953. Increasing forage yields and sheep production on intermountain winter ranges. U.S. Dep. Agric. Circ. 925.

Johnson, W. M. 1953. Effect of grazing intensity upon vegetation and cattle gains on ponderosa pine-bunchgrass ranges of the front range of Colorado. U.S. Dep. Agric. Circ. 929.

Johnston, P. W., G. M. McKean, and K. S. Daily. 1996. Objective 'safe' grazing capacities for southwest Queensland Australia. Aust. Rangel. J. 18:244-258.

Klipple, G. E. and R. E. Bement. 1961. Light grazing - Is it economically feasible as a range improvement practice? J. Range Manage. 14:57-62.

Klipple, G. E. and D. F. Costello. 1960. Vegetation and cattle responses to different intensities of grazing on shortgrass ranges of the central Great Plains. U. S. Dept. Agr. Tech. Bull. 1216.
Lacey, J., E. Williams, J. Rolleri, and M. Marlow. 1994. A guide for planning, analyzing, and balancing forage supplies with livestock demand. Montana State Univ. Ext. Publ. EB-101.

Launchbaugh, J. L. 1957. The effect of stocking rate on cattle gains and on native shortgrass vegetation in west central Kansas. Kansas Agr. Exp. Sta. Bull. 394.

Martin, S. C. 1975. Stocking strategies and net cattle sales on semidesert range. U.S. Dept. Agr. For. Serv. Res. Pap. RM-146.

Natural Resources Conservation Service. 1997. Range and Pasture Handbook. United States Dept. of Agr., Washington, DC.

Paulsen, H. A. and F. N. Ares. 1962. Grazing values and management of black grama and tobosa grasslands and associated shrub ranges of the southwest. U. S. Dept. Agr. Tech. Bull. 1270.

Schwan, H. E., J. Hodges, and C. N. Weaver. 1949. Influence of grazing and mulch on forage growth. J. Range Manage. 2:142-148.

Thurow, T. L. and C. Taylor, Jr. 1999. Viewpoint; The role of drought in range management. J. Range Manage. 52:413-419.

Troxel, T. R. and L. D. White. 1989. Balancing forage demand with forage supply. Texas A\&M Univ. Ext. Serv. Publ. B-1606.

Valentine, K. A. 1970. Influence of grazing intensity on improvement of deteriorated black grama range. N. Mex. Agric. Exp. Stn. Bull. 553.

Ward, N. 1998. Sustainable ranching: A rancher's perspective. Rangelands 20(3):33-37.

Ward, N. 1999. Ranchers need support for sustainable ranching: What government can do: A rancher's perspective. Rangelands 21(3):13-17.

White, L. D. and A. McGinty. 1997. Stocking rate decisions. Texas A\&M Univ. Agr. Ext. Serv. Publ. 13-5036.

Winder, J. A., C. C. Bailey, M. Thomas, and J. L. Holechek. 2000. Breed and stocking rate effects on Chihuahuan Desert cattle production. J. Range Manage. 53:32-38.

Authors are private range consultant, Las Cruces, New Mexico, 88005 ; assistant professor of range science, University of Juarez, Juarez, Mexico; and graduate research assistants and professor, Department of Animal and Range Sciences, New Mexico State University, Las Cruces, New Mexico 88003. This paper was supported by the New Mexico Agricultural Experiment Station and was part of project 1-5-27417.

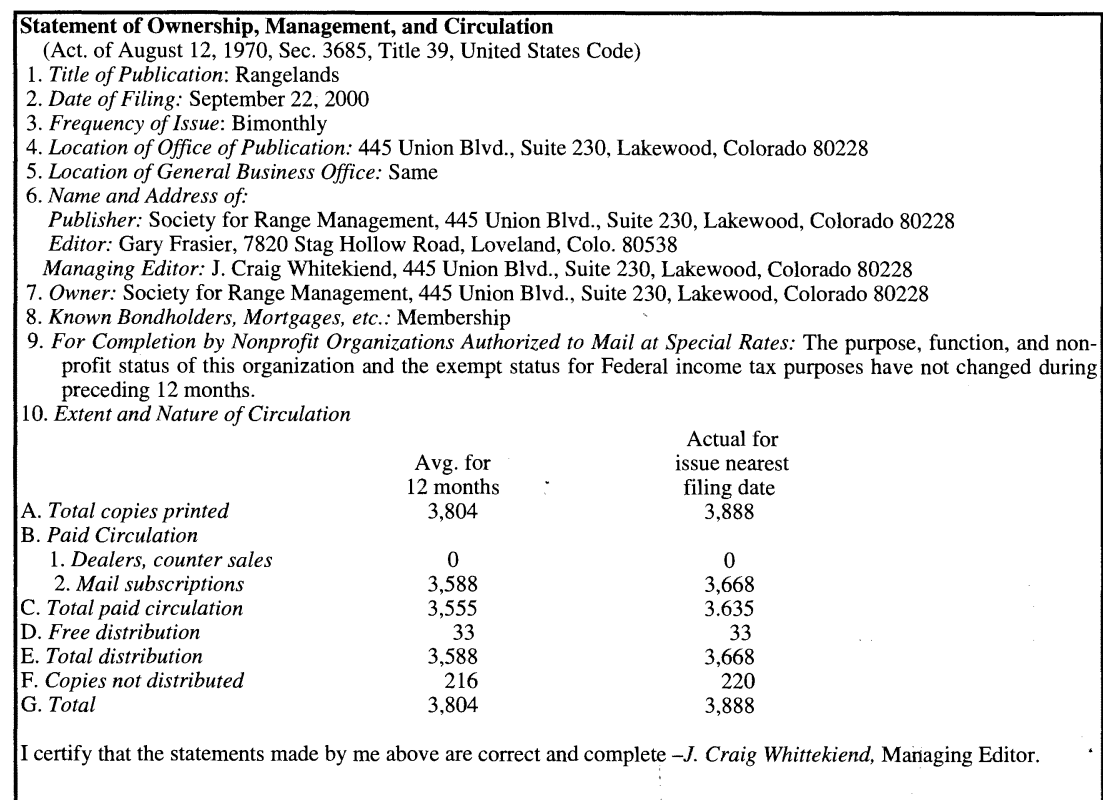

